mean level of serum vitamin $B_{12}$ among smokers is significantly less than among non-smokers. They discuss various factors which may have affected the serum $B_{12}$ level, but they do not mention folate deficiency, which is common during pregnancy.

Low serum $B_{12}$ levels have been observed in over $40 \%$ of patients with megaloblastic anaemia due to folate deficiency, and the levels rise slowly to within the normal range on treatment with folic acid alone.12 As Dr. McGarry and Miss Andrews have not published the serum folate levels in their group of pregnant women, it is not possible to draw conclusions from the $B_{12}$ levels unless all the women were taking folic acid.-I am, etc.,

J. Forshaw

Sefton General Hosp.tal,

Liverpool

1 Mollin, D. L., Waters. A. H., and Harris, E., in Vitamin B12 and Intrinsic Factor, Europäisches Symposium, Hamburg. ed. H. C. Heinrich, p. The

Forshaw, J., and Harwood, L., fournal of Clinical
Pathology, 1971, 24, 244.

\section{Truncal Vagotomy and Pyloroplasty}

SIR.-Mr. F. I. Tovey (29 January, p. 311) is quite right in advising surgeons working in developing countries against a reversion to the old policy of gastrectomy for duodenal ulcer. In my own experience with peptic ulcer surgery among rural patients, mostly refugees from erstwhile East Pakistan resettled in this region over the past 13 years, the patients were happier after vagotomy and drainage, as they could resume their bulky diets more easily. Truncal vagotomy did not produce troublesome diarrhoea in any of our patients. The drainage procedure was to a great extent determined by the site and state of the ulcer.

According to Aird, "1 "in the 'twenties of the present century the commonest site of a duodenal ulcer submitted to operation was the anterior wall of the first part"; but he had "not since the war seen an unperforated ulcer of the antetior wall of the duodenum which could have been locally excised." $\mathrm{He}$ was "tempted to conclude that anterior wall ulcer of the duodenum is always acute, perforating before it can become chronic." In my series ${ }^{2} 56$ out of 95 duodenal ulcers, all chronic and unperforated, were situated on the anterior w-1l. This is interesting and perhaps proves that, in the natural history of duodenal ulcer, India is $40-50$ years behind Britain.

An anterior ulcer, especially with gross scarring and stenosis as seen in many of our cases, may make pyloroplasty technically difficult.-I am, etc.,

ARABinda Mitra

Tagore Hospital,

Dandaka:anya Project,

Kon 'agaon,
Madhya Pradech, India

1 Aird, I., A Companion in Surgical Studies, 2nd edn., p. 707. Edinburgh and London, Living-

Mitra, A., Indian Fournal of Surgery, 1971, 23,

Value of the M.C.V.

SIR.-Recent correspondence ${ }^{2}$ in this journal has indicated the relationship between the red cell mean corpuscular volume (M.C.V.) and mean corpuscular haemoglobin concentration (M.C.H.) when the values are

\begin{tabular}{|c|c|c|c|c|c|c|}
\hline & & 1 & 2 & 3 & 4 & 5 \\
\hline $\begin{array}{l}\text { Haemoglobin }(\mathbf{g} / 100 \mathrm{ml}) \\
\text { Haematocrit }(\%) \\
\text { M.C.V. }\left(\mu^{2}\right) \\
\text { M.C.H. }\end{array}$ & $\begin{array}{l}1 \\
2 \\
3 \\
4 \\
5\end{array}$ & $\begin{array}{l}1.00 \\
0.95 \\
0.22 \\
0.38 \\
0.50\end{array}$ & $\begin{array}{l}1.00 \\
0.19 \\
0.23 \\
0.20\end{array}$ & $\begin{array}{l}1.00 \\
0.91 \\
0.19\end{array}$ & $\begin{array}{l}1.00 \\
0.58\end{array}$ & 1.00 \\
\hline
\end{tabular}

obtained from a Coulter Model "S" automatic counter. We have been conducting in Coventry a haematological survey using this apparatus on a random population sample of 81 male and 89 female subjects aged 65 years and over. As the correlation coefficients were homogenous $(P>0.05)$ in the two sexes, we have pooled the data (Table). Statistically we found little to choose between M.C.H. and M.C.V., which confirms our findings in other population studies where $r$ for this correlation lay between +0.89 and +0.98 .

The poor correlation of the mean corpuscular haemoglobin concentration with either the M.C.V. or M.C.H. is not surprising in view of its curious distribution, ${ }^{3}$ which adds another statistical objection to its use.-We are, etc.,

N. K. SHINTON P. C. ElwoOd

Coventry and Warwickshire Hospital,

1 Rose, M. S., British Medical foumal, 1971, 4, 169.

England, J. M., Walford, D. M., and Waters D. A.' W., British Medical Fournal, 1971, 4.232 : Elwood, P. C., British fournal of Social and
Preventive Medicine, 1964, 18, 81.

\section{Vaccination against Rubella}

SIR,-There are a few points which might, perhaps, be added to Dr. Constance A. C. Ross's comprehensive review of this subject (8 January, p. 109).

Although there is some presumptive evidence that rubella vaccine will produce a long period of immunity, perhaps lifelong, it should be emphasized that this is presumptive only and that one cannot say definitely that a girl of 12 years immunized against rubella will retain that immunity until the end of her reproductive life. In addition, natural immunity may be maintained by intermittent exposure of the immune to the natural virus, and if the epidemiology of the disease is altered radically by immunization this may prove to be a factor of some importance.

By far the most important place for the transmission of rubella infection is the primary school, and the majority of pregnant women come into contact with the disease through an infected primary school child, either directly or through an intermediate case. In spite of the theoretical advantage of protecting women in their child-bearing years against rubella by immunizing girls before they reach the reproductive age, it may be more logical to immunize children of both sexes before they attend school or kindergarten. This would produce an immune population in the group who were previously most susceptible and were the main vehicles of spread of the disease.

An advantage of this method of protection is that reactions to the vaccine are generally less in children of 4-5 years than in children of 11-14 years; this is important with regard to acceptability of the vaccine by the public. Should the duration of pro- tection of the vaccine prove to be lasting, then adults would be directly as well as indirectly protected.-I am, etc.,

J. S. DoDge

Department of Preventive and Social Medicine,

University of Otago,

\section{Pantie-girdle Syndrome}

SIR,-Recently in this department we have been seeing an increasing number of patients with symptoms ranging from tingling to swelling of the feet and legs, with or without ulceration. Sometimes they present with meralgia paraesthetica. All these patients are wearing pantie-girdles, of a new type which I personally have not seen before. Removal of the pantie-girdle very rapidly produces a "cure."

Most people unfortunately seem to buy one of a size smaller than they should, and all of course are overweight. The age range is from 20 to 70 and over. The older patients combine this pantie-girdle with knickers with elasticated bottoms. It needs little imagination to appreciate what happens to the venous return from the leg. When these patients sit up it acts as a very effective venous tourniquet, and when they cross one leg over another-which many of them have to do because of the brevity of their skirtsit acts as a partial arterial tourniquet.

There has been a lot of correspondence recently about deep vein thrombosis. Such people suffer from chronic venous stasis, and if they are admitted for emergency operation they run an increased risk of deep vein thrombosis. We in this depamtment now refer to it as the "pantie-girdle syndrome." -I am, etc.

Physical Medicine Department,

T. K. Davidson

General Hospital

\section{Inexpensive One-way Screen}

SIR,-In many hospitals the advantages of a one-way window are outweighed by the cost. Not only the price of the window itself, but also that of sound equipment has to be found. While such sophistication is both desirable and possible in a large teaching hospital this is often not the case in a small hospital for the mentally ill or handicapped. A simple but effective one-way screen can, however, be made for little cost-if there is no need for the interview room to be soundproof.

An aperture of suitable size is made in the party wall between two rooms (or even one room and a large broom cupboard). A window frame can then be fitted; it makes a neat finish but is not essential. The opening is covered by fine mesh black nvlon facing material (normally used for interfacing coat collars etc. and available from most drapers at less than $50 \mathrm{p}$ per yard). The material may be stuck down or stapled, the latter method being preferable as wire or equipment may 
then be easily passed through after lifting the staples in one corner.

The observation room is completely blacked out and the room under observation brightly illuminated. The observers should preferably wear dark clothes or a dark smock as white or pale colours will reflect the light coming through from the interview room. The screen is not, of course, sound-proof; while this means the observers must keep still, it obviates the need for microphones, amplifiers, etc.

A notice board can be fitted over (on either or both sides) when the screen is not in use. If the board is fairly thick or padded the rooms will be as sound proof as they ever were. - I am, etc.,

Elizabeth SPINDLER Barton

Meanwood Park Hospital for

the Mentally Handicapped,

Leeds 6

Unbalanced Deoxyribonucleotide Synthesis Caused by Methotrexate

SIR,-The report by Dr. A. V. Hoffbrand and Miss Edith Tripp (15 April, p. 140) of changes in the pools of deoxynucleoside triphosphate in cells exposed to methotrexate is of great interest. Their results are, however, different from those recently reported by Baumunk and Friedman, ${ }^{1}$ who found that the deoxythymidine triphosphate (dTTP) content of HeLa cells was not altered by exposure to methotrexate or 5fluorouracil. Their statement that a rise in deoxyadenosine triphosphate (dATP) levels inhibits ribonucleotide reductase, although certainly true for some bacterial and mammalian systems, is not true for all mammalian cells. ${ }^{2}$ Furthermore, the ribonucleotide reductase activity of bone marrow cells from patients with pernicious anaemia has been found to be greatly increased, ${ }^{3}$ and this would appear to conflict with Dr. Hoffbrand and Miss Tripp's suggestion that ribonucleotide reduction may be inhibited in megaloblastic cells. Lastly, their suggestion that DNA ligase activity may be inhibited in methotrexate treated cells is a most interesting and easily testable hypothesis. However, Cleaver ${ }^{4}$ has studied DNA repair in $\mathrm{HeLa}$ cells exposed to a wide variety of cytotoxic agents. He was unable to demonstrate any defect in DNA repair in cells exposed to cytosine arabinoside or fluorodeoxyuridine, both agents which induce megaloblastic change.

I have measured the pools of purine and pyrimidine deoxynucleoside triphosphates in mouse L5178Y lymphoma cells following their exposure to methotrexate. ${ }^{5}$ In every experiment the level of dTTP in treated cells has been reduced, but no consistent change in dATP has been found. It may be that the discrepancy between my results and those of Dr. Hoffbrand and Miss Tripp is explained by the different cell lines studied and by the fact that my cells are a heterogenous population while the latters' cells are synchronized by their exposure to phytohaemagglutin.

Finally, a mechanism for the well-recognized masking of megaloblastosis by iron deficiency ${ }^{6}$ does emerge from Dr. Hoffbrand and Miss Tripp's observation. Iron is a cofactor for mammalian ribonucleotide reduction 26 and in its absence reduction of ADP $\rightarrow$ dADP will be inhibited, thus pre- venting a rise in the dATP level, which they maintain is the basis for megaloblastic change.-I am, etc.,

\section{H. N. Tattersall}

Chester Beatty Research Institute,

Royal Cancer Hospital,

Baumunk, C. N., and Friedman, D. L., Cancer Research, 1971, 31, 1930

Fuiloka, S., Acta Haematologica, 1971, 45, 136. 3 Fuivoka, S., and Silber, R., Fourmal, of Laboratory

Cleaver. J. E., Radiation Research, 1969, 37, 334.

Tattersail, M. H. N., Furness, M. E., Jackson,
S., and Harrap, K. R., Proceedings of the Biochemical Society, in press.

Van der Weyden, M., Rother, M., and Firkin,
B., British foumal of Haematology, 1972, 22,

\section{Removal of Extruded I.U.D.}

SIR,-Six days after reading Dr. Ursula E. Mountrose and Mr. W. L. Whitehouse's letter (8 April, p. 113) recommending colpotomy to remove an I.U.D. extruded into the pouch of Douglas a 23-year-old patient was referred complete with $x$-ray (Fig.). The Lippes loop had been inserted on 6 April 1972, six weeks after confinement, with no difficulty or symptoms at that time, but the threads could not be seen or felt five days later. The only subsequent complaint had been vague pelvic discomfort.

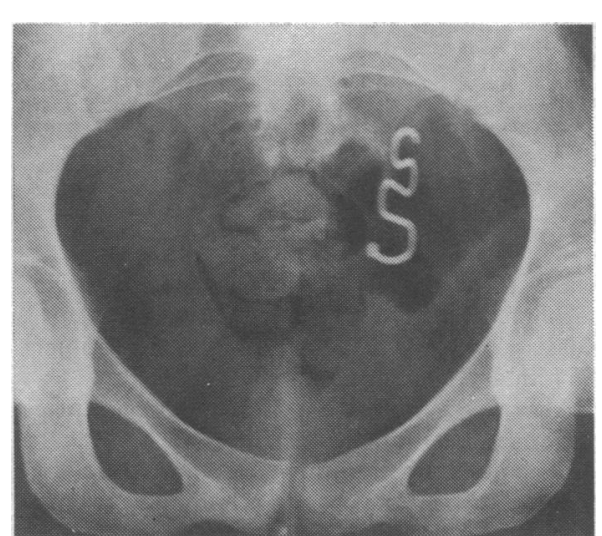

The uterus was anteverted and well involuted, and on careful bimanual examination the loop could be felt in the hollow of the sacrum. She was admitted with her breast-fed baby two days later for colpotomy under anaesthesia. One finger through into the pouch of Douglas easily located and removed the loop. There was no reaction and she went home 48 hours later. I would agree with Dr. Mountrose and Mr. Whitehouse that colpotomy should be considered whenever the extruded loop remains in the pelvis.-I am, etc.,

Department of Obstetrics and Gynaecology,

R. R. MACDONALD

University of Leeds

\section{Bran and Diverticular Disease}

SIR,-As Mr. Neil S. Painter and others (15 April, p. 137) refer to my own experience, it may be constructive to say that I used unprocessed bran in the Royal Navy for some 30 years. At first I experimented cautiously on myself, but my first communication (22 March, 1941, p. 461) described 10 years of constantly-widening experience with this material. I was at that time the senior medical officer of the battleship King George $V$ and, owing to the scarcity of fresh fruit and vegetables, found such bran invaluable for correcting the constipation afticting the ship's company. The ship's canteen bought the bran by the hundredweight-sack and sold it at the present equivalent of only $1 \mathrm{p}$ per $\mathrm{lb}-$ which amount often lasted a man for several weeks. The sailors loved the stuff by comparison with purgatives, and on one occasion, when the supply failed, many fell in at "Captain's Request-Men" to ask if it could be restored, as they felt its loss greatly. I think it is a great tragedy of our present age that, with M.R.C. workers ${ }^{12}$ showing at least $15 \%$ of the population to be on regular purgatives, this precious material is ever lost through the manufacture of white flour.

I have not only used unprocessed bran with almost invariable success among thousands of naval personnel at sea, as described above, but also for nearly 20 years during specialist duties as a physician in naval hospitals, where I always declined to prescribe aperients, relying on an enema if any serious arrest was already present and then solely on the unprocessed bran for future prevention. I can understand that old or frail people would require gradual habituation to it but this was never a problem in the Navy, as long as the bran was taken before meals, to prevent any overloading of the stomach. Meanwhile, the cheapness and naturalness of this product not only facilitate its use on an institutional scale, but also correct certain vitamin deficiencies that can be very real in old people, especially if living alone.

I must disagree entirely over one crucial point in Mr. Painter and colleagues' article. The introduction of the roller mills in 1880 made precious little difference to the amount of fibre removed from the flour. The reason for this is that the fibre (bran) is placed by nature on the outside of the grain, to protect it from injury. Therefore it is the first substance to be removed in the milling. Indeed, Horder, Dodds, and Moran ${ }^{3}$ have shown clearly that even a $90 \%$ flour (that is one that contains $90 \%$ of the whole grain) has already lost two-thirds of the fibre present, and the extra loss of fibre that arose when the old stone-milled $80 \%$ flour, introduced over a century earlier, was replaced by the roller-milled $70 \%$ flour around 1880 amounted to only about $1 \%$.

No. As I have argued, ${ }^{45}$ the various diseases that sprang into prominence in the latter part of the nineteenth century, in which I included the intestinal conditions of appendicitis and diverticular disease. owed much to the refining of flour, but still more to the refining of sugar, the consumption of which, as shown in my chart in Mr. Painter's article, was rising at that time with frightening speed. Not only is much more fibre lost in the refining of sugar, but the effect of the sugar on the prolif ${ }^{\circ}$ ration of the $E$. coli and other bacterial inhabitants of the intestines is of decisive importance.

None of this, however, in any way alters the importance of a true wholemeal bread in our nutrition today, and far from reducing its bran content to any extent whatsoever, it is far more logical to add an extra $10 \%$ of bran, so as to effect at least some compensation for the fibre lost in the refining of sugar. This extra bran adds to, rather than detracts from, the flavour. and such bread is now being increasingly produced in London as the "bran plus" loaf which I have described in our joint work. Such bread is obviously of particular indica- 